\title{
THE EFFECT OF SERVICE QUALITY AND CUSTOMER TRUST ON CUSTOMER SATISFACTION AND CUSTOMER LOYALTY PT SURYA RAFI BERSAUDARA
}

\author{
Untung Surapati ${ }^{1}$, Suharno ${ }^{2}$, Zainal Abidin ${ }^{3}$ \\ Faculty of Economics and Business, Mulawarman University \\ Email : untung.kbs@gmail.com,suharno@feb.unmul.ac.id, zainal.abidin@feb.unmul.ac.id
}

\begin{abstract}
This study aims to determine the effect of service quality and customer trust on customer satisfaction and customer loyalty of PT Surya Rafi Bersaudara. The population in this study were customers of PT Surya Rafi Bersaudara with a total of 75 respondents. The method of data collection is done by giving a list of questions or questionnaires to respondents who are customers at PT BKI, where the questionnaire is distributed to these customers. This study uses a data analysis tool that is partial Least Square (PLS), then this study uses the analysis method of structural equation models or Path Analysis to determine the causal relationship between latent variables contained in structural equations. The tool used in data processing using the Smart PLS program. The results of this study indicate that 1) service quality has a significant effect on customer satisfaction, 2) customer trust has a significant effect on customer satisfaction, 3) service quality has a significant effect on customer loyalty, 4) customer trust has no significant effect on customer loyalty, 5) customer satisfaction has a significant effect on customer loyalty.
\end{abstract}

Keywords: $\quad$ Service Quality, Customer Trust, Customer Satisfaction, Customer Loyalty

\section{Introduction}

Every business must face competition in the era of free trade. One of them is competition in the ship building and ship repair provider sector. Various kinds of services manufacture and repair are offered the market. The number of producers provider of manufacture and repair vessels were grown in Indonesia make the actors of business in the sector is to be able to compete to dominate the market. Many ways that can be done to be able to compete, among them is to always pay attention to service quality and customer trust.

At the moment this in Samarinda already many who open a business venture provider of manufacture and repair vessels, one of which is PT Surya Rafi Bersaudara. PT. Surya Rafi Bersaudara is a company Shipyard Ships are located in East Kalimantan, precisely in the area of the hamlet of loa crow, RT, 20 loa kulu , Kutai mammal . The Company is an official stand on the date of May 19, 2012 by deed of notary No. 04 by notary Natalia sulistio ., SH., Mhum ., MKn . PT. Surya Rafi Bersaudara is a specialist company in the construction of ships made of iron with the type of Tug Boat (TB), Landing Craft Tank (LCT) which has proven its quality and performance. Besides ship types such, the company we are also able to compete in quality 
International Journal of Economics, Business and Accounting Research (IJEBAR)

Peer Reviewed - International Journal

Vol-4, Issue-3, 2020 (IJEBAR)

E-ISSN: 2614-1280 P-ISSN 2622-4771

https://jurnal.stie-aas.ac.id/index.php/IJEBAR

and engineering in the construction of vessels of type more like Tugboat, Barge, Self Propelled Oil Barge (SPOB), Supply Vessel and so forth.

Various attempts to do a company to be able to retain customers that exist. Efforts were made by PT Surya Rafi Bersaudara to retain customers is to give priority to service quality and customer trust are there so that the level of satisfaction of customers and the loyalty of the customers high. Satisfaction of customers is key in creating loyalty of customers. With Thus, the key so that the company still exists is the ability of the company to retain its customers. When the customer leaves, the company's existence is no longer needed. At PT Surya Rafi Bersaudara sometimes customers are still complaining about the obstacles related to the services that given the company such as the provision of information that is less detailed, besides it sometimes employees who perform service to the customer is less friendly . It it certainly affects the level of satisfaction of the customer to the service that was given to PT Surya Rafi Bersaudara, and of course also will affect the level of loyalty of customers to the company. Research that is done by Leninkumar (2017) with the title of " The Relationship between Customer Satisfaction and Customer Trust on Customer Loyalty ". Variables that are used in the research is that customer satisfaction as variable independent and customer loyalty as a variable dependent. The results of the research have demonstrated the relationship that is positive and significant between customer satisfaction to customer loyalty.

Measurement of the level of satisfaction of customers and loyalty of customers is a way to determine whether the service, the value of the customer, as well as the trust of customers who felt in accordance with the wishes and expectations of the customers . By knowing the wishes and expectations of customers so we can improve the quality of service, value for the customer, and trust it 's own. However, the reality is that PT Surya Rafi Bersaudara still does not understand the wishes and expectations of its customers. Services are given PT Surya Rafi Bersaudara according to the customer is still not optimal, because the customer has not get the information in detail of the services that are offered company. Sometimes the services are supplied also tend to be less friendly to the customers so that customers feel less satisfied and there are some customers who decide to move to a competitor. Research that is done by Carauna (2014) with the title " The effects of service quality and the mediating role of customer satisfaction ". Variables that are used in the research is that service quality as a variable independent and customer satisfaction as the variable dependent. The results of the research have demonstrated the relationship that is positive and significant between service quality to customer satisfaction. In addition to that, the research that is carried out by Kuntari et al. (2014) with the title of "Influence Quality of Services Against Satisfaction And Loyalty Customer ( Survey On Customer Service Station PT Astra International Tbk - Daihatsu Malang)". Variables that are used in the research is that service quality as a variable independent and customer loyalty as a variable dependent. The results of the research have demonstrated the relationship that is positive and significant between service quality on customer loyalty.

According to Tjiptono (2008) service quality has a close relationship with customer satisfaction. So provider of services must provide the quality of service as good as possible so that the relationship closely in terms of satisfaction of customers can be maintained with good. Trust customers to PT Surya Rafi Bersaudara were quite good, although there are some customers who also feel less trust for the completion of the manufacture of ships that occasionally pass the limit of time that has been agreed upon in advance, case this makes some customers feel less satisfied . Research that is done by Bricci et al. (2012) with the title " The Effects of Trust, Commitment and Satisfaction on Customer Loyalty in the distribution sector ". Variables that are used in the study is that the customer trusts as variable independent and customer satisfaction as the variable dependent. The results of the research have demonstrated the relationship that is positive and significant between customer trust towards customer satisfaction 
Factors trust also participated giving contribution to the loyalty of customers. Morgan and Hunt (1994) states that trust is the foundation of the most important in building a relationship marketing are successful and defines trust as something feeling that arises when one party has the confidence of the reliability and integrity of the other . Reichheld and Schefter (2000) states that to gain the loyalty of customers, suppliers especially first must gain the trust of them. PT Surya Rafi Bersaudara should be more professional in running its business as the completion of the work boat that exact time, because some customers complained about not appropriate time to the completion of the work boat that they fill in PT Surya Rafi Bersaudara . It's a bit much of course will affect the level of loyalty of customers to the company. In addition to that, the research that is carried out by Upamanyu (2015) with the title " The Effect Of Customer Trust On Customer Loyalty And Repurchase Intention: The Moderating Influence Of Perceived Csr ". Variables that are used in the study is that the customer trusts as variable independent and customer loyalty as a variable dependent. The results of the research have demonstrated the relationship that is positive between customer trust to customer loyalty.

This study aims to determine the effect of service quality and customer trust on customer satisfaction and customer loyalty of PT Surya Rafi Bersaudara

\section{Literature Review Customer Satisfaction}

According to Kotler and Armstrong (2012: 13) customer satisfaction is the extent to which the perceived performance of the product is in accordance with buyer expectations. If the product's performance falls short of expectations, the buyer is not satisfied. If performance matches or exceeds expectations, the buyer is satisfied or pleased. According to Cadotte, et al (1987) satisfaction of customers is the feeling that arises as a result of evaluation of the experience of the use of the product or service.

According to Afshar, et al (2011) satisfaction of customers is the result of the perception of the customer to the value that is received in the transaction or relationship - in which the value equal to the quality of service that is perceived relative to the price and the cost of acquisition of customers . According to Zeithaml et al (2017: 80) satisfaction of customers is the evaluation of the customers of the product or service in terms of whether the product or service that has been fulfilling the needs and expectations of customers.

Based on some of the definitions that have been described, it can be concluded that customer satisfaction is a customer evaluation of the performance results of a product or service and can exceed consumer expectations for the product.

\section{Customer Loyalty}

Oliver (1999) defines customer loyalty as a commitment to the depth of the consumer to buy back or subscribe on products / services that preferably are consistently in the future, so that led to the purchase of the brand are the same, although there is the influence of situational and effort marketing that led to the potential for the switch.

According to Wirtz and Lovelock (2012:56) the loyalty of customers is the willingness of customers to continue to subscribe at a company in run length, with the purchase and use of goods and services are repetitive and more good again be exclusive, and to recommend it to the others. Kotler and Keller (2009:138) defines loyalty as a commitment that held strong to buy again or subscribe more products or services specified in the future even though there effect situation and business marketing that has the potential to cause switching behavior.

According to Griffin (2010: 4) loyalty is a consumer show the behavior of buying it regularly or there is a condition which requires consumers to buy the little two times within an interval of time specified. 
International Journal of Economics, Business and Accounting Research (IJEBAR)

Peer Reviewed - International Journal

Vol-4, Issue-3, 2020 (IJEBAR)

E-ISSN: 2614-1280 P-ISSN 2622-4771

https://jurnal.stie-aas.ac.id/index.php/IJEBAR

Based on the idea that, to note that loyalty is a commitment from customers who form the loyalty of customers will be a product or service, thus resulting in a customer would do purchase are constantly on the products and services are selected .

\section{Service Quality}

Zeithaml et al. (2006:19) service quality is the level of difference between customer expectations or wants and their perceptions. According to Tjiptono (2014: 268) service quality focuses on efforts to fulfill customer needs and desires and the accuracy of their delivery to balance customer expectations.

According Lupiyoadi (2001) states that service quality is the overall traits and characteristics of a product or service in terms of abilty to meet the needs that have been determined

Sembiring et al (2014), service quality is provide excellence of service that is performed by providers of services to meet the needs and desires customer accuracy delivery to balance the expectations of the customers.

Based on some of the definitions in the above, can be concluded that in the study of this, service quality is the fulfillment of the needs and desires that can exceed the expectations of customers .

\section{Customer Trust}

Isaac and Lutfhi (2011) expressed the belief is willingness to rely to the others who have believed. Purwanto (2014) states that trust is the belief that providers of services can establish a relationship run long with customers, as well as the willingness or belief partner exchange to establish a relationship term long to produce work that is positive.

Thomas (2009: 249) defines trust as a positive result of what is expected, the results that a person receives based on the expectations of the performance of others. Based on some of the definitions in the above, can be concluded that in the study of this, customer trust is a belief that is owned by the consumer to establish a relationship term length to the parties who have believed.

\section{Hypothesis Development}

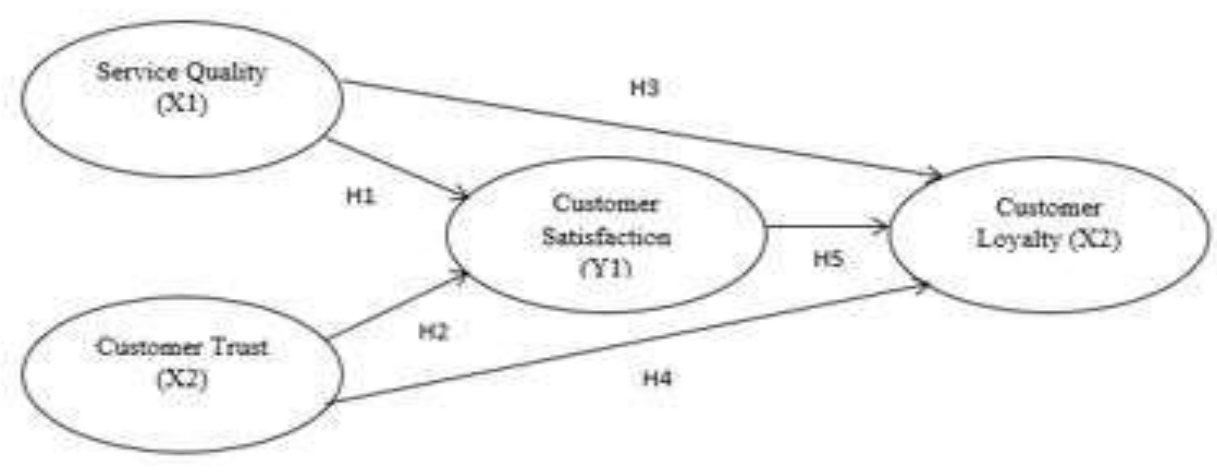

Based on the development of hypotheses as well as the framework of the concept of the above, it can put forward a hypothesis as follows:

1. Service quality affects significantly to costumer satisfaction.

2. Customer trust influenced significantly against costumer satisfaction.

3. Service Quality influential significantly towards costumer loyalty.

4. Customer trust influenced significantly against costumer loyalty.

5. Costumer Satisfaction impact significantly on costumer loyalty. 
International Journal of Economics, Business and Accounting Research (IJEBAR)

Peer Reviewed - International Journal

Vol-4, Issue-3, 2020 (IJEBAR)

E-ISSN: 2614-1280 P-ISSN 2622-4771

https://jurnal.stie-aas.ac.id/index.php/IJEBAR

\section{Research Methods}

\section{Operational Definition and Variable Measurement Customer Satisfaction}

Customer Satisfaction is the evaluation of the customer on the results of the performance of a product or service that is given to PT Surya Rafi Bersaudara and to exceed the expectations of consumers on products such. Indicators that are used are:

1) Conformity of hope, which is the level of conformity between quality of service and quality of products which are expected by consumers with the satisfaction that is felt by consumers in PT Surya Rafi Bersaudara.

2) Interests buy back, which is the willingness of consumers to pay a visit back to buy the products that exist in PT Surya Rafi Bersaudara.

3) Willingness to recommend, which is the willingness of consumers to recommend PT Surya Rafi Bersaudara to friends or family.

\section{Customer Loyalty}

Customer Loyalty is a commitment from customers who form the loyalty of customers will be a product or service, thus resulting in a customer would do purchase are constantly on the products and services of PT Surya Rafi Bersaudara. Indicators that are used are:

1) Make a purchase the product as a regular in PT Surya Rafi Bersaudara.

2) Making purchases outside the product / service line at PT Surya Rafi Bersaudara

3) Customer convey things positive on the product PT Surya Rafi Bersaudara to colleagues or the other.

4) Demonstrate loyalty to the product of PT Surya Rafi Bersaudara than the competitors

\section{Service Quality}

Service Quality is the effort of PT Surya Rafi Bersaudara in fulfilling needs and desires that can exceed customer expectations. Indicators that are used are:

1) Tangible (tangible), is evidence of the physical that can be felt directly by the customers of PT Surya Rafi Bersaudara in the form of the results of the product / service that is given.

2) Reability (reliability), is the ability of PT Surya Rafi Bersaudara to provide the service the best that was promised to the customer.

3) Responsiveness (quick response), is the willingness of PT Surya Rafi Bersaudara to assist and provide services that quickly and precisely to the customer.

4) Assurance (guarantee), is a guarantee of PT Surya Rafi Bersaudara to the products and services that are given to generate trust and confidence to customers Surya Rafi Bersaudara.

5) Emphaty (empathy), is giving attention and concern with service, friendliness, communication, and the ability to understand the needs of PT Surya Rafi Bersaudara customers

\section{Customer Trust}

Customer Trust is the belief that consumers have in establishing a long - term relationship with PT Surya Rafi Bersaudara. Indicators that are used are:

1) Perception Integrity (Integrity), ie the perception of consumers that PT Surya Rafi Bersaudara follow the principles that can be accepted as keeping promises, behaving according ethical and honest.

2) Perception of Kindness (Benevolence), which is based on the amount of trust partnership with PT Surya Rafi Bersaudara who own objectives and motivations that become surplus companies compared to organizations other at the moment the conditions are just emerging, namely the conditions in which the commitment is not formed . 
International Journal of Economics, Business and Accounting Research (IJEBAR)

Peer Reviewed - International Journal

Vol-4, Issue-3, 2020 (IJEBAR)

E-ISSN: 2614-1280 P-ISSN 2622-4771

https://jurnal.stie-aas.ac.id/index.php/IJEBAR

3) Perceived Competence (Competence), namely the ability of PT Surya Rafi Bersaudara to solve the problems that faced by consumers and fulfill all his need.

\section{Population and Sample}

Population according Sugiyono (2014: 148) is a region of generalization which consists on : objects / subjects that have the quantity and characteristics of particular were determined by researchers to learn and then drawn conclusions. The population in the study is that the customers of PT Surya Rafi Bersaudara who totaled 150.

According Sugiyono (2014: 149) sample is part of the number and characteristics of which are owned by the population of the by because of it we establish a representative population of the so-called sample. According to Hair (2010) that the number of samples that is used is calculated by multiplying the number of indicators with a scale of 5 up to 10 . In the study of this there are 15 indicators of research and use numbers multiplier is 5, so that the number of samples of his research are as follows:

Number of samples $=15 \times 5=75$ samples $/$ respondent

\section{Data Collection Techniques}

The data used in this study are primary data and secondary data. Secondary data were taken from various literature both offline and online. Primary data is the data that is associated with indicators that obtained from respondents who fill out the questionnaire. The data in this study were collected by several methods, namely as follows:

a. Research library (library research) which searches the materials and theories by studying, researching, reviewing and examining the literature that relates to the problem that will be investigated.

b. Observation, namely the collection of data through observation directly on the object that is observed.

c. Questionnaires, namely data collection by providing a list of questions to respondents that are closed with several alternative answer choices.

d. The interview, which is how the collection of data by referring to the list of questions in advance. How it is useful also to get feedback - feedback that would have not been covered in question questionnaire

\section{Data Analysis Tools}

In a study this using a scale of ratings Likert on a scale of 1-5, where 1 indicates Very not agree and 5 show Highly agree. This study uses a Partial Least Square (PLS) analysis tool. Analysis of Partial Least Square (PLS) is a technique of statistical multivariate who perform a comparison between a variable dependent multiple and variable independent double. PLS is one of the methods of statistical SEM -based variant that is designed to complete regression of multiple when occurred the problems specific to the data, such as the size of the sample of the study of small, their data is lost ( missing values ) and multicollinearity . (Abdillah \& Jogiyanto, 2015: 161).

\section{Results and Discussion}

The validity can be seen based on the outer loading / loading factor value. Loading factor above 0.70 is highly recommended, however, loading factor $0.50-0.60$ can still be tolerated as long as the model is still in the development stage. 
International Journal of Economics, Business and Accounting Research (IJEBAR)

Peer Reviewed - International Journal

Vol-4, Issue-3, 2020 (IJEBAR)

E-ISSN: 2614-1280 P-ISSN 2622-4771

https://jurnal.stie-aas.ac.id/index.php/IJEBAR

\begin{tabular}{|c|c|c|c|}
\hline \multirow{4}{*}{ Outer Loading of Each Construct } \\
\hline \multirow{4}{*}{ Variable } & & & \\
& Indicator & Original Sample & Value Boundary \\
\hline \multirow{4}{*}{ Service Quality } & & & \\
\cline { 2 - 4 } & $\mathrm{X} 1.1$ &, 872 & 0.7 \\
\cline { 2 - 4 } & $\mathrm{X} 1.2$ &, 871 & 0.7 \\
\cline { 2 - 4 } & $\mathrm{X} 1.3$ &, 939 & 0.7 \\
\cline { 2 - 4 } & $\mathrm{X} 1.4$ &, 784 & 0.7 \\
\hline \multirow{3}{*}{ Customerer Trust } & $\mathrm{X} 2.5$ &, 892 & 0.7 \\
\cline { 2 - 4 } & $\mathrm{X} 2.2$ &, 841 & 0.7 \\
\cline { 2 - 4 } & $\mathrm{X} 2.3$ &, 935 & 0.7 \\
\hline \multirow{3}{*}{ Customer Satisfaction } & $\mathrm{Y} 1.1$ &, 919 & 0.7 \\
\cline { 2 - 4 } & $\mathrm{Y} 1.2$ &, 992 & 0.7 \\
\cline { 2 - 4 } & $\mathrm{Y} 1.3$ &, 839 & 0.7 \\
\hline \multirow{3}{*}{ Customer loyalty } & $\mathrm{Y} 2.1$ &, 823 & 0.7 \\
\cline { 2 - 4 } & $\mathrm{Y} 2.2$ &, 809 & 0.7 \\
\cline { 2 - 4 } & $\mathrm{Y} 2.3$ &, 796 & 0.7 \\
\cline { 2 - 4 } & $\mathrm{Y} 2.4$ &, 901 & 0.7 \\
\hline
\end{tabular}

Source : SmartPLS output

Measurement of the discriminant validity of the measurement model is assessed based on the cross loading value. If the value of cross loading of each indicator of the variable in question is more substantial than the corss loading variables other, the indicators are valid.

Cross Loading Value

\begin{tabular}{|c|c|c|c|c|}
\hline & $\begin{array}{c}\text { Customer Trust } \\
\left(\mathbf{X}_{2}\right)\end{array}$ & $\begin{array}{c}\text { Service } \\
\text { Quality }\left(\mathbf{X}_{1}\right) \\
\end{array}$ & $\begin{array}{c}\text { Customer } \\
\text { Satisfaction }\left(\mathbf{Y}_{1}\right)\end{array}$ & $\begin{array}{c}\text { Customer } \\
\text { Loyalty }\left(\mathbf{Y}_{2}\right) \\
\end{array}$ \\
\hline X1.1 & 0.704 & 0.872 & 0.635 & 0.675 \\
\hline $\mathrm{X} 1.2$ & 0.802 & 0.871 & 0.773 & 0.820 \\
\hline X1.3 & 0.840 & 0.939 & 0.757 & 0.822 \\
\hline X1.4 & 0.574 & 0.784 & 0.438 & 0.566 \\
\hline $\mathrm{X} 1.5$ & 0.804 & 0.892 & 0.742 & 0.773 \\
\hline X2.1 & 0.841 & 0.718 & 0.684 & 0.676 \\
\hline $\mathrm{X} 2.2$ & 0.935 & 0.771 & 0.726 & 0.771 \\
\hline $\mathrm{X} 2.3$ & 0.919 & 0.836 & 0.798 & 0.853 \\
\hline Y1.1 & 0.786 & 0.742 & 0.892 & 0.762 \\
\hline Y1.2 & 0.782 & 0.702 & 0.928 & 0.812 \\
\hline Y1.3 & 0.609 & 0.640 & 0.839 & 0.782 \\
\hline Y2.1 & 0.688 & 0.694 & 0.730 & 0.823 \\
\hline Y2.2 & 0.652 & 0.638 & 0.738 & 0.809 \\
\hline Y2.3 & 0.652 & 0.647 & 0.713 & 0.796 \\
\hline Y2.4 & 0.850 & 0.837 & 0.769 & 0.901 \\
\hline
\end{tabular}

Source : Author compiled

Another way of knowing the discriminant validity of a variable can be obtained from the square root AVE of a construct compared to the correlation value between other constructs. If the value is higher than the correlation between other constructs, it can be concluded that the research instrument meets the criteria for discriminant validity. 
International Journal of Economics, Business and Accounting Research (IJEBAR)

Peer Reviewed - International Journal

Vol-4, Issue-3, 2020 (IJEBAR)

E-ISSN: 2614-1280 P-ISSN 2622-4771

https://jurnal.stie-aas.ac.id/index.php/IJEBAR

Average Variance Extracted (AVE) and AVE Root

\begin{tabular}{|c|c|c|}
\hline & AVE & Information \\
\hline Service Quality & 0.762 & Valid \\
\hline Customer Trust & 0.808 & Valid \\
\hline Customer Satisfaction & 0.787 & Valid \\
\hline Customer Loyalty & 0.694 & Valid \\
\hline
\end{tabular}

Source : Primary data that is processed

The outer model reliability test can use the PLS output seen from the Cronbach Alpha value. In general, it is stated that the criteria for the alpha coefficient are said to be reliable if alpha> 0.6. So that if according to the specified criteria, the alpha value is greater than 0.6 , it is declared reliable.

Value Cronbach Alpha

\begin{tabular}{|c|c|c|}
\hline & Cronbachs Alpha & Information \\
\hline Service Quality & 0.922 & Reliable \\
\hline Customer Trust & 0.881 & Reliable \\
\hline Customer Satisfaction & 0.864 & Reliable \\
\hline Customer Loyalty & 0.852 & Reliable \\
\hline
\end{tabular}

Source : Primary data that is processed

In addition, the reliability of latent variables with reflective indicators is evaluated based on the results of composite reliability. Variable latent said reliable if it has a value of composite reliability and iindikator which measure a variable latency of the more substantial or above of 0.70 (reliability high). The following table presents the reliability test results of all latent variables with their respective reflective indicators.

Composite Reliability

\begin{tabular}{|c|c|c|}
\hline & Composite Reliability & Information \\
\hline Service Quality & 0.941 & Reliable \\
\hline Customer Trust & 0.927 & Reliable \\
\hline Customer Satisfaction & 0.917 & Reliable \\
\hline Customer Loyalty & 0.901 & Reliable \\
\hline
\end{tabular}

Source: Primary data that is processed

Goodness of Fit Model Check

Knowing the goodness-fit of the model can be seen from the R-Square value. The R-Square value can be used to explain the effect of the independent variable on the dependent variable having a substantive effect.

\begin{tabular}{|c|c|c|c|}
\multicolumn{5}{|c|}{ R - Square } \\
\hline No. & Variable & R Square & R Square Adjusted \\
\hline 1. & Customer Satisfaction & 0.696 & 0.688 \\
\hline 2. & Customer Loyalty & 0.855 & 0.849 \\
\hline
\end{tabular}

Source : Author compiled

\section{Hypothesis Test Results}

Path Coefficients

\begin{tabular}{|l|l|l|l|l|l|}
\hline & $\begin{array}{l}\text { Original } \\
\text { Sample }\end{array}$ & $\begin{array}{l}\text { Sample } \\
\text { Mean }\end{array}$ & $\begin{array}{l}\text { Standard } \\
\text { Deviation }\end{array}$ & $\begin{array}{l}\text { T- } \\
\text { Statistics }\end{array}$ & P Values \\
\hline
\end{tabular}


International Journal of Economics, Business and Accounting Research (IJEBAR)

Peer Reviewed - International Journal

Vol-4, Issue-3, 2020 (IJEBAR)

E-ISSN: 2614-1280 P-ISSN 2622-4771

https://jurnal.stie-aas.ac.id/index.php/IJEBAR

\begin{tabular}{|l|c|c|c|c|c|}
\hline $\begin{array}{l}\text { K1 Service Quality } \\
\begin{array}{c}\text { Y1 Customer } \\
\text { Satisfaction }\end{array}\end{array}$ & 0.291 & 0.295 & 0.134 & 2,178 & $\mathbf{0 . 0 3 3}$ \\
\hline $\begin{array}{l}\text { X1 Service Quality } \\
->\quad \text { Y2 Customer } \\
\text { Loyalty }\end{array}$ & 0.286 & 0.298 & 0.100 & 2,847 & $\mathbf{0 . 0 0 6}$ \\
\hline $\begin{array}{l}\text { X2 Customer Trust } \\
-\quad \quad \text { Y1 Customer } \\
\text { Satisfaction }\end{array}$ & 0.570 & 0.559 & 0.132 & 4,320 & $\mathbf{0 , 0 0 0}$ \\
\hline $\begin{array}{l}\text { X2 Customer Trust } \\
-\quad \quad \text { Y2 Customer } \\
\text { Loyalty }\end{array}$ & 0.208 & 0.210 & 0.117 & 1,777 & $\mathbf{0 . 0 8 0}$ \\
\hline $\begin{array}{l}\text { Y1 Customer } \\
\text { Satisfaction } \\
\quad->\text { Y2 Customer } \\
\text { Loyalty }\end{array}$ & 0.490 & 0.474 & 0.088 & 5,565 & $\mathbf{0 , 0 0 0}$ \\
\hline
\end{tabular}

Source : Primary data that is processed

\section{Discussion}

H1: Stating that it is getting better Service Quality influence positive and significant will be getting better Customer Satisfaction. The results of testing the hypothesis value T-statistics for 2.178>1.96, which means that the hypothesis which states Service Quality influence positively and significantly to the Customer Satisfaction proven true or hypothesis is first received.

H2: Stating that the better Customer Trust has a positive and significant effect, the higher the Customer Satisfaction. Based on the results of testing the hypothesis in mind that Customer Trust gives the effect that positively and significantly on Customer Satisfaction with the value of T-statistics for 4.320>1.96. So that the results of this study are in accordance with the second hypothesis which states that Customer Trust has a positive and significant effect on Customer Satisfaction or the second hypothesis is accepted.

H3: Stating that the better Service Quality has a positive and significant effect, the higher the Customer Loyalty. Based on the results of testing the hypothesis in mind that the Service Quality gives the effect that positively and significantly on Customer Loyalty with the value of T-statistics for 2.847> 1.96. So that the results of this study are in accordance with the third hypothesis which states that Service Quality has a positive and significant effect on Customer Loyalty. The third hypothesis is accepted.

H4: Stating that the better Customer Trust has a positive but not significant effect on Customer Loyalty. Based on the results of testing the hypothesis in mind that Customer Trust gives the effect that positive is not significant to the Customer Loyalty with the value of Tstatistic of $1.777<1.96$. So that the results of this study are not in accordance with the fourth hypothesis which states that Customer Trust has a significant effect on Customer Loyalty is not proven true or the fourth hypothesis is rejected.

H5: Stating that the increasingly high level of Customer Satisfaction influence positively and significantly it will be increasingly high customer loyalty. Based on the results of testing the hypothesis note that Customer Satisfaction gives the effect that positively and significantly to customer loyalty with value $\mathrm{T}$ statistics by 5.565> 1.96. So that the results of this study are in accordance with the fifth hypothesis which states that Customer Satisfaction has a significant effect on Customer Loyalty proven true or the fifth hypothesis is accepted. 
International Journal of Economics, Business and Accounting Research (IJEBAR)

Peer Reviewed - International Journal

Vol-4, Issue-3, 2020 (IJEBAR)

E-ISSN: 2614-1280 P-ISSN 2622-4771

https://jurnal.stie-aas.ac.id/index.php/IJEBAR

\section{Effect of Service Quality of Customer Satisfaction}

Based on the results of the analysis and test hypotheses with the value of the t- statistic is more substantial than t- table, then the variable Service Quality influence positively and significantly to Customer Satisfaction. The results of the analysis that illustrates that the variable Service Quality which consists of indicators tangible, reability, responsiveness, assurance, and empathy that there currently is able to create the effect on Customer Satisfaction. It is demonstrated that the indicators were used in the study is able to encourage the creation of Customer Satisfaction. Results The mean customers of PT Surya Rafi Bersaudara feel happy and helped with the availability of the services that are offered by PT Surya Rafi Bersaudara. Costs which issued the customer can be measured by customer and have a perception of value that was issued in accordance with the benefit that is received.

\section{Influence Customer Trust Of Customer Satisfaction}

Customer Trust gives the effect that positively towards Customer Satisfaction, meaning that more and better Customer Trust who felt customers will be getting better or higher Customer Satisfaction. With a T-statistics value of 4,320> 1.96 which means a significant relationship to Customer Satisfaction. PT Surya Rafi Bersaudara Samarinda has been able to create a Customer Trust which is good for customers. Consumers believe the services are supplied by PT Surya Rafi Bersaudara were able to meet their needs. The results of this means consumers have trust to PT Surya Rafi Bersaudara with his ministry to be able to give satisfaction to the consumer. PT Surya Rafi Bersaudara were able to understand the needs of customers who feel getting ease with the service that was given.

\section{Effect of Service Quality of Customer Loyalty}

Based on the results of testing the hypothesis in mind that the Service Quality gives the effect that positively and significantly on Customer Loyalty. With a T-Statistics value of 2.847> 1.96 so that the results of this study are in accordance with the third hypothesis which states that Service Quality has a significant effect on Customer Loyalty. The meaning of the study 's Service Quality able to create customer loyalty to the service that was given to PT Surya Rafi Bersaudara Samarinda. Hypothesis accepted. The results of this meaningful service quality conducted by PT Surya Rafi Bersaudara have succeeded in creating a Customer Satisfaction in getting the ease of service which is supplied with either. PT Surya Rafi Bersaudara were able to understand the needs of customers who feel getting ease with the service that was given.

\section{Influence Customer Trust to Customer Loyalty}

Based on the results of hypothesis testing, it is known that Customer Trust has a positive but not significant effect on Customer Loyalty. It is significant that even better Customer Trust effect positive but do not affect it significantly towards Customer Loyalty. In research it looks that customer trust has not been able to increase customer loyalty that exist in PT Surya Rafi Bersaudara, things have happened because the customer is believed to use the services of the company, but not necessarily the customers that will be loyal to the company. It is able to occur because the customers also consider matters other outside the study as the number of providers of services are similar that would make customers too expensive to use services that offer companies another so that the variable customer trust in research is not influenced significantly to customer loyalty.

\section{Influence Customer Satisfaction of Customer Loyalty}

Based on the results of testing the hypothesis note that Customer Satisfaction gives the effect that positively and significantly on Customer Loyalty with the value of T-statistics for 5.565> 1.96. So that the results of this study are in accordance with the fifth hypothesis which states 
International Journal of Economics, Business and Accounting Research (IJEBAR)

Peer Reviewed - International Journal

Vol-4, Issue-3, 2020 (IJEBAR)

E-ISSN: 2614-1280 P-ISSN 2622-4771

https://jurnal.stie-aas.ac.id/index.php/IJEBAR

that Customer Satisfaction has a significant effect on Customer Loyalty proven true or hypothesis 5 is accepted. Results The mean Customer Satisfaction which was created by PT Surya Rafi Bersaudara were able to satisfy the customer as the provider of the service services so that case this will be able to increase customer loyalty PT Surya Rafi Bersaudara.

\section{Conclusion}

Based on the results of the analysis and discussion in the chapter before, it can be drawn conclusions as follows:

a. Based on the research results, Service Quality will increase the Customer Satisfaction of PT Surya Rafi Bersaudara which means that it has a positive and significant effect on Customer Satisfaction. Meaningful PT Surya Rafi Bersaudara has been able to provide care services that they offer to their customers. PT Surya Rafi Bersaudara must be able to continue to provide the quality service desired by its customers and strive to improve services that are able to maintain Service Quality in customer perceptions.

b. Based on the research results, the increase in Customer Trust will increase the Customer Satisfaction of PT Surya Rafi Bersaudara, which means that it has a positive and significant effect on Customer Satisfaction. PT Surya Rafi Bersaudara must be able to maintain customer trust in using the services of PT Surya Rafi Bersaudara. Customer Trust is one of the factors that is very important in shaping Customer Satisfaction. PT Surya Rafi Bersaudara must be able to provide a positive experience to its customers so that it is able to maintain and get a response according to customer perceptions.

c. Based on the results of the research Service Quality influence positively and significantly on Customer Loyalty PT Surya Rafi Bersaudara with the value of the $t$ statistic is more substantial than $t$ table. So that the results of this study are in accordance with the third hypothesis which states that customer trust has a positive and significant effect on customer loyalty, hypothesis 3 is accepted.

d. Customer Trust has a positive but not significant effect on Customer Loyalty. PT Surya Rafi Bersaudara have not been able to create a Customer Trust were positive in the perception of the customer to be able to directly loyal. With the value of the $t$ statistic is smaller than $t$ table, so that the results of the study is not in accordance with the hypothesis of the four who expressed customer trust affects positively and significantly to customer loyalty or hypothesis 4 is rejected.

e. Customer Satisfaction has a positive and significant effect on Customer Loyalty. PT Surya Rafi Bersaudara were able to create customer loyalty through the Customer Satisfaction in the perception of customers. With the value of the $t$ statistic is more substantial than $t$ table, so that the results of the research is in accordance with the hypothesis fifth that express customer satisfaction impact positively and significantly to customer loyalty or hypothesis 5 is accepted

\section{Suggestion}

Based on the results of the analysis that has been concluded, the researcher can provide the advice useful for the parties are related, among others :

1. PT Surya Rafi Bersaudara should be able to continue to provide improvement of Service Quality that when this has been appropriate and able to give satisfaction to the customer.

2. Customer Trust is one of the factors that is very important in shaping Customer Satisfaction. PT Surya Rafi Bersaudara should be able to provide the confidence that has been appropriate time is in giving satisfaction to the customers so it is able to maintain and got a response Customer Trust in accordance perceptions of customers.

3. PT Surya Rafi Bersaudara must be able to maintain Service Quality that is appropriate at this time in forming Customer Loyalty while using the services of PT Surya Rafi Bersaudara 
according to the perception of customers of PT Surya Rafi Bersaudara, and become a company consideration in making decisions to increase Customer Loyalty.

4. Variable Customer Trust is not significant to the customer loyalty, the results of research is in accordance with the research that is done Tabarani \& Amin, (2018) which revealed that customers trust effect is not significant to the customer loyalty . It is because of customer trust towards the service that is given, but the things that do not make consumers become loyal to the company. The study further should consider indicators other can increase customer loyalty.

5. PT Surya Rafi Bersaudara should be able to maintain Customer Satisfaction him who formed Customer Loyalty PT Surya Rafi Bersaudara Customer Satisfaction may cause the loyalty of customers of PT Surya Rafi Bersaudara. Companies must maintain indicators that form Customer Satisfaction that lead to loyalty to the use of the services of PT Surya Rafi Bersaudara.

6. The results of the research it can be used as a reference the research further to develop research that is more advanced.

7. Research which carried out subsequently can use the objects and places are different so it can compare several objects of research.

\section{Refernces}

Afshar, A., \& Corresponding, J. (2011). Study the Effects of Customer Service and Product Quality on Customer Satisfaction and Loyalty. International Journal of Humanities and Social Science , 1 (7), 253-260.

Arokiasamy, ARA, \& Tat, HH (2014). Assessing the Relationship Between Service Quality and Customer Satisfaction in the Malaysian Automotive Insurance Industry. Journal of Scientific Research, $20(9)$, 1030. https://doi.org/10.5829/idosi.mejsr.2014.20.09.12029

Cadotte, ER, Woodruff, RB, \& Jenkins, RL (1987). Expectations and Norms in Models of Consumer Satisfaction. Journal of Marketing Research,24(3), 305. https://doi.org/10.2307/3151641

Chinomona, R. (2014). Does Customer Satisfaction Lead to Customer Trust, Loyalty and Repurchase Intention of Local Store Brands? The Case of Gauteng Province of South Africa. Mediterranean Journal of Social Sciences, 5 (9), 2332. https://doi.org/10.5901/mjss.2014.v5n9p23

Ferdinand, A. (2014). Management Research Methods. Diponegoro University Publishing Agency.

Fian, J. Al, \& Yuniati, T. (2016). Marketing \& Business Research. Journal of Management Science and Research , 5 (6).

Gentile, C., Spiller, N., \& Noci, G. (2007). How to Sustain the Customer Experience: European Management Journal, 25 (5), 395410. https://doi.org/10.1016/j.emj.2007.08.005

Ghozali, I., \& Latan, H. (2014). Partial Least Square: Concepts, Methods \& Applications Using the Warppls 4.0 Program (2nd ed.). Undip.

Griffin, J. (2010). customer loyalty: how to earn it, how to keep it. In mc. graw hill . https://doi.org/10.1007/BF01932569

Guenzi, P., Johnson, MD, \& Castaldo, S. (2009). A comprehensive model of customer trust in two retail stores. Journal of Service Management, 20 (3), 290316. https://doi.org/10.1108/09564230910964408

Isaac, A. (2011). The Effect of Satisfaction and Consumer Trust on Loyalty: A Study on the Role of Mediation. Journal of Business Strategy , 5 (1), 55-66. 
International Journal of Economics, Business and Accounting Research (IJEBAR)

Peer Reviewed - International Journal

Vol-4, Issue-3, 2020 (IJEBAR)

E-ISSN: 2614-1280 P-ISSN 2622-4771

https://jurnal.stie-aas.ac.id/index.php/IJEBAR

Jogiyanto. (2011). BUSINESS RESEARCH METHODOLOGY (BPFE-YOGYAKARTA (ed.); 4th ed.). BPFE-YOGYAKARTA.

Kotler, P., \& Armstrong Gery. (2012). Principles of Marketing Channel Management. In Pearson Prentice Hall (14th ed.). https://doi.org/10.2307/1250103

Kotler, P., \& Keller, kevin lane. (2009). MARKETING MANAGEMENT (J. Purba (ed.); 12th ed.). PT.indeks.

Lita, RP (2009). The Effect of Trust on Customer Loyalty Commitments. Trichonomics , 8 (2), $71-77$.

Lo Liang Kheng, Osman Mahamad, TR (2010). The Impact of Service Quality on Customer Loyalty: A Study of. International Journal of Marketing Studies, 2(2), 5766. https://doi.org/10.5539/ijms.v2n2p57

Lupiyoadi, R. (2001). Service Marketing Management (3rd Edition) . Four Salemba.

Morgan, Robert M., \& Hunt, shelby D. (1944). Commitment Thrust Theory - Marketing Relationship.pdf. Journal of Marketing , 58, 20-38.

Naeem, H., Akram, A., Jinnah, F., \& Saif, MI (2009). Service Quality and Its Impact on customer satisfaction: An Empirical Evidence from the Pakistani Banking sector. International Business \& Economics Research Journal , 8 (12), 99-104.

Nidyatantri, NMM, Suryawardani, IG. O., \& Agung, DG (2016). The Effect of Satisfaction and Trust on Consumer Loyalty of Japanese Soybean Edamame Approach to Structural Equation Modeling. Journal of Agribusiness and Agro-tourism , 5 (1).

Oliver, richard L. (1999). whence consumer loyalty? Journal of Marketing , 63 , 33-44.

Parvez, N., \& Akbar, MM (2009). Impact of service quality, trust, and customer satisfaction on customer loyalty. ABAC Journal , 29 (1), 24-38.

Purwanto Agus Budi. (2014). Product Quality Development Model in Order to Achieve Customer Trust and Loyalty (STUDI. Journal of Economic Focus , 9 (1), 96-108.

Reichheld, F., \& Schefter, P. (2000). E-loyalty: your secret weapon on the web. Harvard Business Review , 105-113.

Ribbink, D., Riel, ACR Van, Liljander, V., \& Streukens, S. (2004). comfort your online customer: quality, trust and loyalty on the internet. Managing Service Quality, 14 (6), 446-456. https://doi.org/10.1063/1.3033202

Saglik, E., Gulluce, C., Kaya, U., \& Ozhan, KC (2014). Service Quality and Customer Satisfaction Relationship: A Research in Erzurum Ataturk University Refectory. American International Journal of Contemporary Research , 4 (1), 100-117.

Sembiring, Inka Janita, Suharyono, \& Kusumawati, A. (2014). The Effect of Product Quality and Service Quality on Customer Satisfaction in Forming Customer Loyalty (Study on Customer McDonald's MT.Haryono Malang). Annales Pharmaceutiques Francaises , 68 (2), 1-10. https://doi.org/10.1080/00423114.2017

Sembiring, IJ (2014). Customer Satisfaction in Forming Customer Loyalty (Study on McDonald's Customer MT. Haryono Malang). Journal of Business Administration, 15 (1), 1-10.

Setiawan, H., \& Sayuti, AJ (2017). Effects of Service Quality, Customer Trust and Corporate Image on Customer Satisfaction and Loyalty: An Assessment of Travel Agencies Customer in South Sumatra Indonesia. IOSR Journal of Business and Management , 19 (05), 31-40. https://doi.org/10.9790/487x-1905033140

Shanka, MS (2012). Bank service quality, customer satisfaction and loyalty in Ethiopian banking sector. Journal of Business Administration and Management Sciences Research , 1 (1), 001-009.

Tabrani, M., \& Amin, M. (2018). Trust, commitment, customer intimacy and customer loyalty in Islamic banking relationships International Journal of Bank Marketing Article information: August . https://doi.org/10.1108/IJBM-03-2017-0054 
International Journal of Economics, Business and Accounting Research (IJEBAR)

Peer Reviewed - International Journal

Vol-4, Issue-3, 2020 (IJEBAR)

E-ISSN: 2614-1280 P-ISSN 2622-4771

https://jurnal.stie-aas.ac.id/index.php/IJEBAR

Tu, Yu-Te; Li, Mei-Lien; Chih, H.-C. (2013). An Empirical Study of Corporate Brand Image, Customer Perceived Value and Satisfaction on Loyalty in Shoe Industry. Journal of Economics and Behavioral Studies , 5 (7), 469-483. https://doi.org/10.14257/astl.2014.48

Tumini, \& Pratiwi Mega Dwi. (2016). The influence of service quality and trust on customer loyalty at the autobus akas iv probolinggo company . 286-300.

Wirtz, J., \& Lovelock, C. (2012). marketing services .

Zahir Osman. (2013). an Empirical Study of Direct Relationship of Service Quality, Customer Satisfaction and Customer Trust on Customer Loyalty in Malaysian Rural Tourism. Journal of Tourism, Hospitality \& Culinary Arts , 6 (2), 192-206.

Zeithaml, VA, Bitner, MJ, \& Gremler, DD (2017). Services Marketing: Integrating Customer Focus Across the Firm, 6th Edition . 